Jusmal llmial

PFUR AT DE

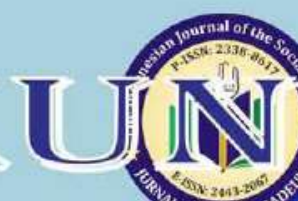

Vol. 5, No. 3, September 2017

$\int_{\substack{\text { Indrjesident } \\ \text { si in }}} 1$

sCAD Intependent Acreditatiou by 100 since 2014 $\bigodot$ Copernicus Publications

\section{JIP}

The Indonesian Journal of the Social Sciences www.journal.scadindependent.ors D01 Prefix Number; 10,26811
Csinta

INDEX COPERNICUS 


\title{
THE CURRENT SITUATION AND TREND OF THE LABOR FORCE OF MINING SECTOR IN MONGOLIA
}

\author{
Altanchimeg Zanabazar1; Myagmarsuren Ukhnaa2; Huo Xuexi3; \\ Shurentsetseg Bira ${ }^{4}$; Sarantuya Jigjiddorj5; Odgerel Pagvajav ${ }^{6}$ \\ 1,4,5,6 National University of Mongolia (NUM) \\ 2,3Northwest A\&F University (NWAFU) of China \\ ${ }^{1}$ Contributor Email: altanchimeg_zana@yahoo.com
}

Received: May 19, 2017

Accepted: Sep 22, 2017

Published: Sep 28, 2017

Article Url: http://journal.scadindependent.org/index.php/jipeuradeun/article/view/175

\begin{abstract}
The mining was declared as a priority sector within the framework of the government policy to support the export industries. In the past years, the mining extraction increased steady and growth showed an increase of 8.3 percent in 2012 compared to the previous year, 19.4 percent in 2013 and 24.4 percent in 2014 respectively. In the current stage when the mining sector production plays a crucial role in the accumulation of the state budget, one of the key issues of improving the benefits of this sector is the impact of the labor force. By the labor market survey of 2013 out of 219013 job offers 14541 jobs or 6.6 percent were in the mining exploration sectors. Due to the mining sector booming, the job opportunities have increased and there is a need for the government policy and regulations for the education policies, curriculum modifications of the universities, colleges and vocation training as well as labor migration. According to the results of the study, the major challenge for the mining sector is lack of creative, enthusiastic and professional personnel. Therefore, identification of the accurate government policies that would ensure the balance between supply, the demand for the human resources in the mining sector and cohesion of the stakeholders are becoming essential.
\end{abstract}

Keywords: Mining Sector, Labor Force Demand and Supply, Skilled Personnel 


\section{A. Introduction}

The mining sector was declared as a priority economic sector of the country in the national development policy based on the national goals of the millennium challenge of Mongolia and sanctioned to conduct geological surveying utilizing public funding as well as to explore the strategic deposits. ${ }^{1}$

By2014 the GDP reached 21844.2 bln MNT and compared to the previous year it increased by 14.3 percent. The main contributors to the present growth of GDP were increases of agriculture 13.5 percent, mining sector 29.7 percent and construction 16.3 percent. The impact of the mining sector to GDP in the past ten years presented in table 1.

Table 1 Gross Domestic Product of Mongolia (by sector )

\begin{tabular}{|c|c|c|c|c|c|c|c|c|}
\hline $\begin{array}{l}\text { Economic } \\
\text { sectors }\end{array}$ & 2007 & 2008 & 2009 & 2010 & 2011 & 2012 & 2013 & 2014 \\
\hline Total & $4,956,6472$ & $6,555,569.4$ & $6,590,637.1$ & $9,756,588.4$ & $13,173,763.4$ & $16,688,419.6$ & $19,118,002.6$ & $21,844,250,3$ \\
\hline $\begin{array}{l}\text { Agriculture, } \\
\text { forestry, } \\
\text { fishery, and } \\
\text { hunting }\end{array}$ & 913,4092 & $1,259,660.8$ & $1,177,380.3$ & $1,144,697.9$ & $1,357,866.8$ & $1,878,786.4$ & $2,603,632.5$ & $3,108,275.5$ \\
\hline $\begin{array}{l}\text { Mineral } \\
\text { extraction }\end{array}$ & $1,340,8544$ & $1,324,247.7$ & $1,285,899.7$ & $2,102,157.9$ & $2,536,239.6$ & $2,742,750.5$ & $2,965,592.7$ & $3,845,376.3$ \\
\hline Manufacturing & $309,500.4$ & $430,179.4$ & $425,000.6$ & $664,315,3$ & $931,377.5$ & $1,248,666.3$ & $1,708,320.1$ & $1,948,570.7$ \\
\hline Construction & $106,421.1$ & $122,051.0$ & $86,238.7$ & $250,230.7$ & $402,828.3$ & $837,487.5$ & $973,859.9$ & $1,138,382.3$ \\
\hline Others & $2,286,462.1$ & $3,419,430.5$ & $3,616,117.8$ & $5,594,686.6$ & $7,945,451.2$ & $9,980,728.9$ & $10,861,597.4$ & $11,803,645.5$ \\
\hline
\end{tabular}

Source: NSO statistical booklet, 2014

By the average of the past 3 years, the mining made 16.5 percent of GDP and composed 40 percent of the budget revenue and more than 90 percent of the export.

1 "National development policy based on the Millennium challenge goals of Mongolia",/Parliament resolution of Mongolia, 2008. 
Figure 1 Share of the mining sector in Mongolian economy

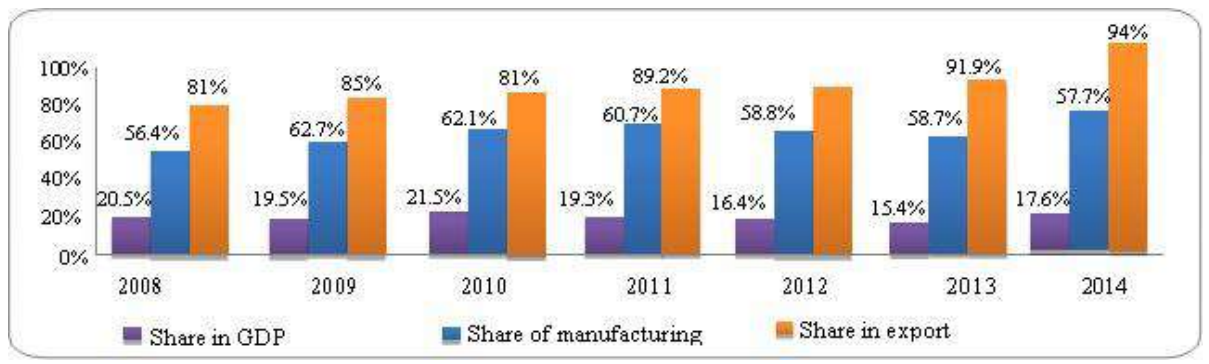

Especially, the main export commodities such as mintage, copper concentrate, iron ore and concentrate, crude oil made 86 percent of the total export or 76 percent of the supply.

Currently, more than 10 mining products are extracted and exported as concentrate upon primary processing. ${ }^{2}$

By January 21, 2015 in total 1284 companies are engaged in the current sector and employ 47415 employees for the permanent and temporary jobs. ${ }^{3}$

Figure 2 Information on companies and work force of the mining sector

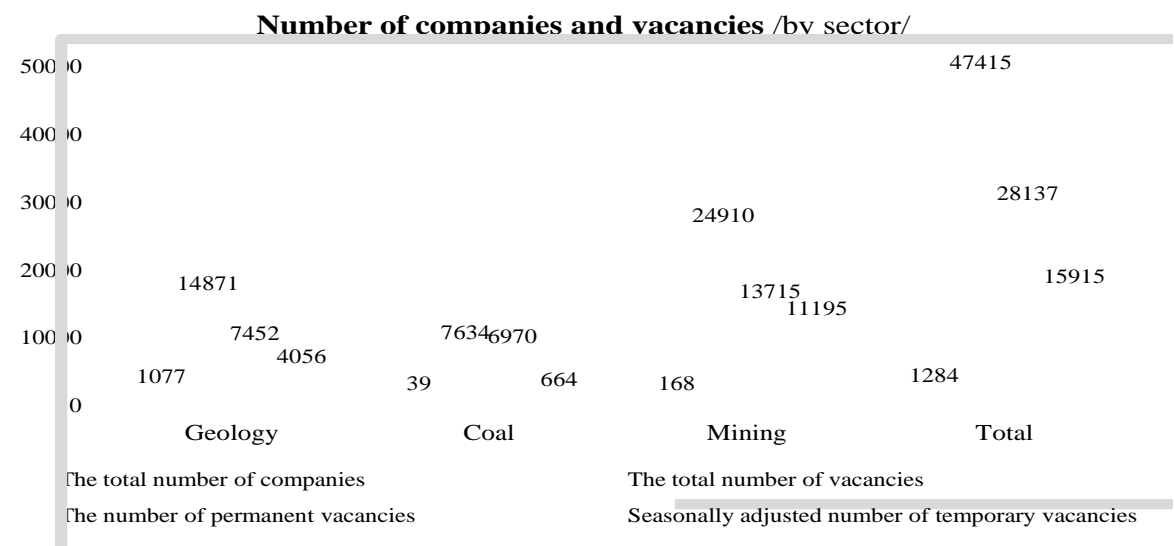

If we consider the employment of expatriate personnel occupied the labor market 5125 personnel or 57,8 percent of them with the technical

\footnotetext{
${ }^{2}$ Current situation of the mining sector study conducted by Mandal General LLC, 2014.

3 "Review of thecurrent mining sector 2014.
} 
and engineering backgrounds and it demonstrates the existing needs for skilled technical personnel in our country.

The mining sector employs 1445 expatriate personnel or 16.3 percent of the expatriates and the second largest sector employ the foreign labor force is the construction.

\section{B. Method}

We focus on practical implications for Mongolian policymakers. However, our methods and findings might have implications for other developing countries. The Mongolian labor market is strong in many dimensions, and some trends, such as the level of education and the degree of formality, are moving in a positive direction. But there are also problems. In this section, we provide policy suggestions for addressing these problems and further improving the employment situation in Mongolia.

Finally, analysts should work to establish evidence on causal relationships between specific programs or policies and economic outcomes, and between macroeconomic performance and the labor market. We noted that government services should be evaluated, but this can go further. In the area of establishing the relationship between policies and outcomes, randomized controlled trials and other rigorous methods to determine causal mechanisms will be useful, as will designing policies to include a monitoring and evaluation component that can incorporate improvements during implementation. Generally, the research methodology that we use is a mixed method.

\section{Discussion}

Mongolia has implemented numerous policies and actions towards to the development of the human resources of the mining sector. In preparation of the professionals for the mining and energy sectors number of academic and vocational institutions contributed significantly including manufacturing school served from 1939, school of handcrafters 
started in 1944, manufacturing school since 1948, manufacturing school established adjunct to the Sov Mongol metal association established in 1950, Faculty of Energy of the NUM from 1961 and Faculty of Mining launched in 1972. ${ }^{4}$

Presently, professionals of the mining sector are prepared at the various higher education institutions such as Applied Science School of NUM, School of Geology MUST, Mining engineering school, Erdenet School of Technology, Darkhan School of Technology and several private institutions are also involved.

The following types of institutions are involved in the education of the mining professionals in Mongolia:

1. Universities and colleges

2. School of Technology

3. Vocational Training Schools

Among the universities and colleges state-owned universities including MUST, University of Geology and Mining, MUST branch School of Technology in Darkhan, Erdenet, and Uvurkhangai, Germany invested Mongolian German joint university of minerals and technology that started its operation a year ago offering an undergraduate degree in mining refinery engineering. As the university started in August 2014 they enrolled 21 fulltime students and 30 students for the foundation program. The state university of Mongolia is a private institution that has 9 majors in mining and producing mining specialists in the labor market during the past 6 years.

Overall 1979 students graduated from the School of Geology \& Mining, MUST in 2011-2014.

To provide more opportunity for accessing vocational education and to meet the existing need for the qualified skilled workers, the vocational training centers are established considering five geographical zones of Mongolia. The vocational training centers operating at the Mechanical engineering school of MUST, at the College of Polytechnics, MUST, at Polytechnic College branch of MUST, Mining vocational center

${ }^{4}$ G. Batzorig, 2012, "90 years to the prosperity" 
in Govisumber aimag, a vocational training center in Nalaikh district of Ulaanbaatar city and at the Manufacturing and Design College.

Vocational training centers offer the types of the programs:

1. Professional education certificate program for 2.5 years;

2. Professional certificate program for 1 year.

Moreover, Oyu Tolgoi project funded training is offered at the vocational centers. The schools and mining professional fields are shown in the below table.

Table 2 Mining Majors at the Universities and Colleges

\begin{tabular}{|c|c|c|}
\hline № & $\begin{array}{c}\text { Universities \& } \\
\text { colleges }\end{array}$ & Majors \\
\hline & \multicolumn{2}{|r|}{ Universities } \\
\hline 1 & $\begin{array}{l}\text { Mongolian } \\
\text { University of } \\
\text { Sciences and } \\
\text { Technology } \\
\text { (MUST) }\end{array}$ & $\begin{array}{l}>\text { Mining management } \\
>\text { Mining electrical facilities } \\
>\text { Survivor } \\
>\text { Mining machinery } \\
>\text { Plotting } \\
>\text { Plotting and informatics } \\
>\text { Mining technology exploitation } \\
>\text { Mineral refinery technology } \\
>\text { Cadastre }\end{array}$ \\
\hline 2 & $\begin{array}{l}\text { State University } \\
\text { of Mongolia }\end{array}$ & $\begin{array}{l}>\text { Engineer in mining technology exploitation } \\
>\text { Mining management } \\
>\text { Mining machinery } \\
>\text { Electrical engineer } \\
>\text { Engineer in exploitation of electrical facilities } \\
>\text { Mineral refinery technology } \\
>\text { Surveying combustible minerals } \\
>\text { Geological engineer } \\
>\text { Renewal energy } \\
>\text { Auto engineering } \\
>\text { Industry automation }\end{array}$ \\
\hline & \multicolumn{2}{|r|}{ Technology school } \\
\hline 1 & $\begin{array}{c}\text { School of } \\
\text { Technology } \\
\text { branch of MUST } \\
\text { in Darkhan }\end{array}$ & $\begin{array}{l}>\text { Mining exploration technology } \\
>\quad \text { Mining management }\end{array}$ \\
\hline 2 & $\begin{array}{c}\text { School of } \\
\text { Technology } \\
\text { branch of MUST }\end{array}$ & $\begin{array}{l}>\text { Mining exploration technology } \\
>\quad \text { Mining management }\end{array}$ \\
\hline
\end{tabular}




\begin{tabular}{|c|c|c|}
\hline & in Erdenet & \\
\hline 3 & $\begin{array}{l}\text { Sh. Otgonbileg } \\
\text { school of } \\
\text { technology }\end{array}$ & $\begin{array}{l}>\text { Уул уурхайн цахилгаан тоног төхөөрөмж, } \\
\text { ашиглалт } \\
>\text { Mining exploitation of electrical facilities } \\
>\text { Mining exploration technology } \\
>\text { Mineral, mining refinery technology }\end{array}$ \\
\hline 4 & $\begin{array}{l}\text { Polytechnical } \\
\text { college of MUST } \\
\text { since } 1954 \\
\text { /Vocational } \\
\text { Training school/ }\end{array}$ & $>$ Mining electrician \\
\hline & \multicolumn{2}{|r|}{ Vocational Training center } \\
\hline 1 & $\begin{array}{l}\text { Vocational } \\
\text { training centers }\end{array}$ & $\begin{array}{l}>\text { Mining electrician } \\
>\text { Mining maintenance } \\
>\text { Excavator operator } \\
>\text { Repairman of mining machinery } \\
>\text { Bulldozer operator } \\
>\text { Drill operator / exploration and surveying / }\end{array}$ \\
\hline 2 & $\begin{array}{l}\text { Oyu Tolgoi } \\
\text { project } \\
\text { sponsored } \\
\text { training }\end{array}$ & $\begin{array}{l}\text { Maintenance worker for refinery, exploration } \\
\text { and mining equipment \& machinery. } \\
\text { Mining restoration, reforestation worker } \\
\text { /vocational professional certificate program/ } \\
\text { Mining electrical, Heavy machinery operator, a } \\
\text { maintenance worker for heavy machinery are } \\
\text { trained through Vocational certificate programs } \\
\text { to satisfy the personnel needs of the company. }\end{array}$ \\
\hline
\end{tabular}

According to the projection made by the Labor, institute71848 jobs will be available in the current sector in 2017 and 91480 jobs will be created. Although in the 2013-2014 academic year in private and public universities and colleges 3933 students enrolled in 6 mining majors both undergraduate and post graduate levels and they represent only 2.6 percent of the total number of students studied that year.

The government of Mongolia has been taking measures and giving significance for preparing highly qualified mining specialists in the overseas prestigious higher education institutions and doubled study abroad related funding and more than 50 students receive a grant in aid 
scholarships of foreign countries. However, no improvements and visible changes have resulted.

\section{Recommendations and Conclusion}

Based on the above reviews we proposed a model that would enable enhancing the sustainability of the supply and demand of the labor force of the mining and interrelation of the stakeholders.

Model on meeting demand \& supply of mining sector.

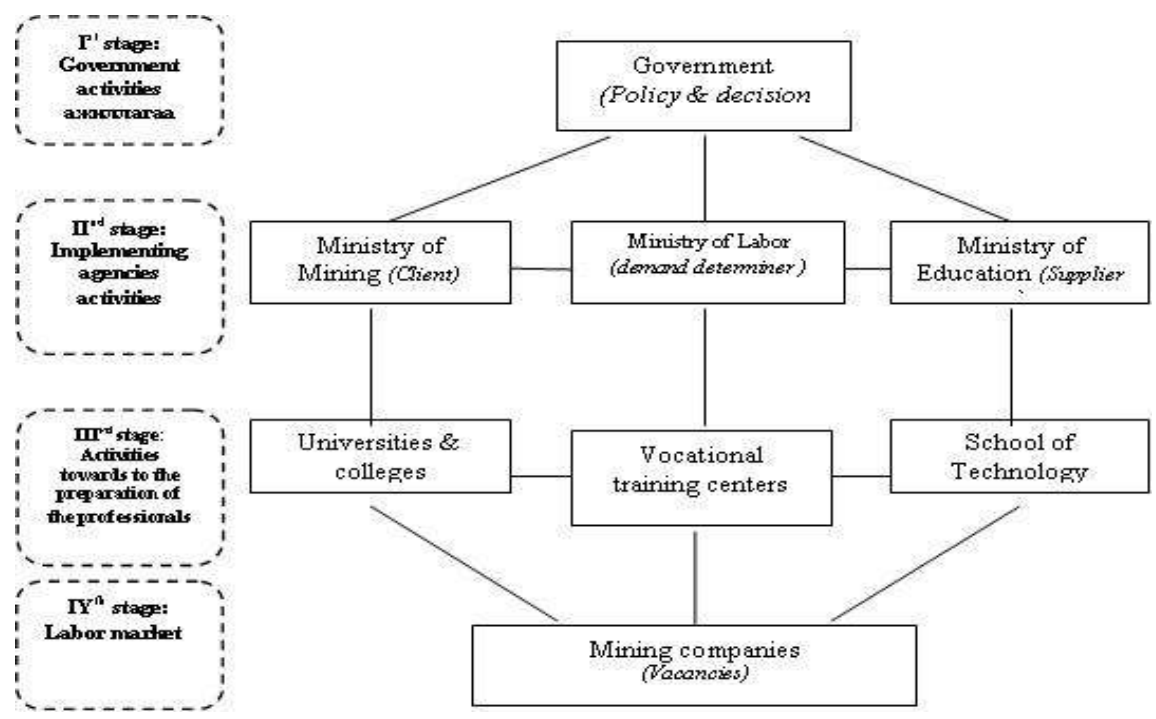

Recommendations Based on the Model

\section{Ist stage: Government}

1) Review ineffective government decisions and resolutions on labor force of the mining sector issued previously and reformulate and optimize the decisions with respect to the present conditions and enforce them; and

2) Create a favorable legal environment for implementing the government policy and enabling better collaboration among implementing agencies, businesses working in the mining, local government leaders, trade unions and civic organizations.

\section{II ${ }^{\text {nd }}$ stage: Implementing agencies}


1) Establish vocational training centers at the major mining companies that will enable providing an industry based learning environment and obtaining skills and hands-on experiences;

2) Create a possibility to improve the professional's skills for the personnel who are already working in the industry and students majoring in mining and increase the number of mining majors and joint programs;

3) Establish electronic database on labor force who will join the sector; and

4) Intensify promotion of occupations among secondary schools and increase enrollment quota for the vocational training center, technical colleges, and university applicants.

\section{III ${ }^{\text {rd }}$ stage: Institutions involved in preparing professionals}

1) Increase the number scholarships of mining companies and the Ministry of Mining;

2) Strengthen the quality of the internships and industry practicum sessions of the colleges and institutions to better meet labor market requirements and implement government funded project to address the quality of teaching and learning; and

3) Study the focus areas of the businesses in cooperating with the students and increase interests of the businesses to involve the students in solving industry issues through the industrial practicum and internship.

\section{IV th stage: Companies}

1) Enhance and expand university and business cooperation;

2) Improve the working environment and social welfare of the employees at the businesses; and

3) Strengthen Human Resource planning and policy.

\section{Bibliography}

Altanchimeg, Z., Battuya, D., \& Tungalag, J. (2016). The Current Circumstances and Challenges of Migrant Labor Force of Mongolia in North Eastern Asia. Jurnal Ilmiah Peuradeun, 4(1), 27-38. 
Batchuluun J., Bekhtur., B. (2004). “Labor market” Ulaanbaatar, p.224.

Chimed-Oidov., S. Byambajav. Ts. (1989). "Labor management and planning", Ulaanbaatar, p.143.

Economic review of Mongolia. (2014). study conducted by Bank of Mongolia.

Ganbaatar., S. (2011). "Challenges of the human resources of the mining sector", Ulaanbaatar.

Government of Mongolia programs in 2012-2016. proposal / Parliament resolution of Mongolia, 2012.

Narantsetseg., P. (2003). “Mongolian management: Challenges and solutions" Ulaanbaatar, p.98.

National development policy based on the Millennium challenge goals of Mongolia". (2008). Parliament resolution of Mongolia.

National Statistical Office". (2014). Mongolia bulletin, Ulaanbaatar.

Reference book on vocational training centers. (2011). National Statistical Office, Mongolia.

Sarangerel., S., Sumjidmaa.,C. (2013). “Dutch disease and mining" Ulaanbaatar.

Some policy issues of the mining sector. (2014). Open Society Forum, Mongolia Mining Mongolian Journal. 2014, №. 10 (072).

Study by the public authority of Geology and Mining. (2010), Ulaanbaatar.

The current situation of the mining sector. (2014). Study conducted by Mandal General LLC.

Tsolmontuya., D. (2009). “Crisis impacting mining sector of Mongolia and economical prospects of the country", Ulaanbaatar.

Шуренцецег. В., Амарсанаа.В.Некоторие вопросы, связанные с политикой управления человеческими ресурсами горной промьшшенности Монголий.Проблемы недропользования, Международный ФорумКонкурс Молодых Ученых. Сборник научных трудов. Част II.25-27 апреля 2012 г., Санкт-Петербург, 109-110 стр. 